\title{
LOCUS EDUCATIONIS \\ SEBAGAI PENGUATAN PENDIDIKAN KARAKTER DI SEKOLAH MENUJU PESERTA DIDIK YANG BERBUDI
}

\author{
Oleh: I Nyoman Sueca \\ Dosen pada Institut Hindu Dharma Negeri Denpasar
}

\begin{abstract}
ABSTRAK
Sekolah dapat menjadi wahana pendidikan karakter yang andal dan efektif bagi pembentukan idividu. Sekolah dapat memanfaatkan locos educationis di dalam lembaga pendidikan sebagai praksis pendidikan karakter. Sejak dahulu sekolah memiliki dua tujuan utama dalam karya pendidikan mereka, yaitu membentuk manusia yang cerdas, dan berbudi luhur. Mundurnya pendidikan karakter, kita wajib bertanya kembali pada diri sendiri dan pada orang lain terkait relevansinya pendidian karakter dalam sekolah. Kalau masih relevan, bagaimana kita sekarang mau menghidupkan kembali, dan melalui momen-momen pendidikan (locus educationis) mana, kita dapat memberikan pendidikan karakter itu di dalam diri peserta didik. Hancurnya nilai-nilai moral dalam masyarakat yang ditandai dengan merebaknya kekerasan seperti; pemerkosaan gadis dibawah umur, pembunuhan, narkoba dan lain-lainnya, fenomena inilah membutuhkan kelahiran baru pendidikan karakter di dalam sekolah. Momen-momen dalam lingkungan sekolah yang dapat dipakai sebagai sebuah sarana atau kesempatan dalam mengembangkan pendidikan karakter, telah melibatkan jaringan relasional antara staf sekolah dengan orang tua dan masyarakat.
\end{abstract}

Kata Kunci: Sekolah sebagai wahana penguatan pendidikan karakter.

\section{ABSTRACT}

Schools can be a vehicle for character education are reliable and effective for the formation of depressed individuals. Schools can take advantage of locos educationis in educational institutions as educational praxis character. Since the first school to have two main objectives in their educational work, the human form of intelligent and virtuous. The resignation of character education, we shall ask back on yourself and on others related to relevance pendidian characters in school. If it is still relevant, how do we now want to revive, and through moments of education (locus educationis) where we can give the character education in self-learners. The destruction of moral values in a society marked by the outbreak of such violence; rape of a girl under age, murder, drugs and others, this phenomenon requires a new birth of character education in schools. Moments in a school environment that can be used as a means or opportunity to develop character education, has involved a relational network between the staff of the school with parents and the community.

Keywords: School as a vehicle for strengthening character education.

Locus Educationis Sebagai Penguatan Pendidikan Karakter

Di Sekolah Menuju Peserta Didik Yang Berbudi 


\section{PENDAHULUAN}

Sekolah, jika dijiwai dengan semangat pendidikan karakter akan menjadi tempat yang efektif bagi pembentukan individu, sehingga mereka dapat tumbuh dan berkembang dengan baik di dalam lingkungannya. Sejak dahulu sekolah memiliki dua tujuan utama dalam karya pendidikan mereka, yaitu membentuk manusia yang cerdas, dan berbudi luhur. Dengan dua keyakinan inilah sekolah memiliki tanggung jawab besar dalam pendidikan karakter bagi peserta didiknya, terutama melalui disiplin, keteladanan serta kebijakan sekolah dan kurikulum. Sekolahsekolah harus memiliki keberanian untuk menanamkan dalam diri peserta didik, bahwa pemahaman konseptual dan praksis yang dipandu oleh nilai-nilai luhur akan membantu untuk menciptakan sebuah masyarakat yang lebih sehat dan berbudi luhur serta manusiawi.

Mundurnya pendidikan karakter, kita wajib bertanya kembali pada diri sendiri dan pada orang lain terkait relevansinya pendidian karakter dalam sekolah. Kalau masih relevan, bagaimana kita sekarang mau menghidupkan kembali, dan melalui momen-momen pendidikan (locus educationis) mana kita dapat memberikan pendidikan karakter itu di dalam diri peserta didik.

Lingkungan sekolah menjadi tempat pendidikan yang baik bagi pertumbuhan peserta didk. Segala peristiwa yang terjadi disekolah semestinya dapat diintegrasikan dalam program pendidikan karakter. Dengan demikian, pendidikan karakter merupakan usaha bersama dari seluruh warga sekolah untuk menciptakan sebuah kultur baru di sekolah, yaitu kultur pendidikan karakter. Untuk itu ada beberapa lingkungan pendidikan di sekolah yang dapat menjadi lahan tempat pendidikan karakter itu dapat diterapkan baik secara langsung maupun tidak langsung.

Secara langsung lembaga pendidikan dapat menciptakan sebuah pendekatan pendidikan karakter melalui kurikulum, penegakan disiplin, manajemen kelas, maupun melalui program-pogram pendidikan yang telah dirancangnya. Terlebih dengan desentralisasi sekolah yaitu pembentukan otonomi sekolah melalui Kurikulum Tingkat Satuan Pendiddikan (KTSP), bahkan sekaran sudah terlaksana kurikulum berbasis KKNI, sekolahsekolah sesungguhnya diberi kewenangan untuk mengembangkan kurikulum sekolah yang dijiwai dengan pendidikan karakter. Oleh karena itu adanya kurikulum berbasis KKNI merupakan tantangan bagi setiap pendidik untuk dapat memaknai setiap perubahan kurikulum dalam lingkungan sekolah, sehingga nilai-nilai pendidikan karakter di sekolah benar-benar menjadi jiwa dalam proses pembelajaran peserta didik di dalam kelas maupun di luar kelas.

Secara tidak langsung sekolah dapat memberikan pendidikan karakter dengan cara menciptakan sebuah lingkungan moral yang membantu setiap individu dalam lingkungan pendidikan agar semakin dapat menemukan induvidualitasnya dan menghayati kebebasannya secara lebih penuh. Lingkungan moral yang sehat merupakan sebuah kondisi ketika setiap individu di dalam sekolah merasakan kesejahtraan karena kebebasan dan keunikannya dihargai. Sebab, ketika kita berbicara tentang moral, kita berbicara terutama bagaimana setiap individu itu saling menghargai satu sama lain, menganggap pribadi yang lain itu bernilai didalam dirinya sendiri, dan karena itu tidak dapat ditundukan demi kepentingan yang lain. Manusia bermartabat karena ia adalah manusia, dan karena itu ia tidak dapat dijadikan alat demi tujuan apa pun. Ia adalah tujuan dalam dirinya.

Lingkungan pendidikan yang dimaksud penulis disini adalah momen-momen dalam lingkungan sekolah yang dapat dipakai sebagai sebuah sarana atau kesempatan dalam mengembangkan pendidikan karakter. Momen-momen ini melibatkan jaringan relasional antara staf sekolah (yayasan, guru, karyawan administrasi, dan non keguruan) dengan orang tua dan masyarakat. 
Lingkungan pendidikan sekolah yang menjadi tanah subur bagi pertumbuhan karakter anak didik antara lain, pemahaman tentang sekolah sebagai wahana aktualisasi nilai, penghayatan momen-momen perjumpaan antara guru dengan siswa, baik yang terjadi di dalam kelas maupun di luar kelas.

Sekolah dengan demikian menjadi tempat istimewa bagi penanaman nilai-nilai dan laboratorium bagi latihan pelaksanaan nilai yang membantu mengembangkan individu menjadi pribadi yang semakin utuh, menghayati kebebasan dan tanggung jawab sebagai individu dan makhluk sosial, untuk itu, patutlah ditelaah momen-momen apa saja dalam sekolah yang dapat dijadikan locos educationis pendidikan karakter di dalam pendidikan. Locus educationis itu antara lain: Sekolah sebagai wahana aktualisasi nilai, setiap perjumpaan guru dengan siswa adalah momen pendidikan nilai, wawasan wiyatamandala sekolah, manajemen sekolah, pendidikan agama bagi pemebentukan karakter, pendidikan jasmani dan distorsi bagi pendidikan karakter, pendidikan estetika dan bahayanya bagi pendidikan karakter, dan pengembangan kurikulum secara integral.

\section{PEMBAHASAN}

Penguatan pendidikan karakter di sekolahsekolah merupakan suatu momen dan wahana sebagai aktualisasi sebuah nilai kehidupan masyarakat masa depan. Sekolah sebagai lembaga formal secara tidak langsung sekolah dapat menanamkan pendidikan karakter secara kuat, dengan cara menciptakan sebuah lingkungan moral yang membantu setiap individu dalam lingkungan pendidikan agar semakin dapat menemukan induvidualitasnya dan menghayati kebebasannya secara lebih penuh. Lingkungan moral yang sehat merupakan sebuah kondisi ketika setiap individu di dalam sekolah merasakan kesejahtraan karena kebebasan dan keunikannya dihargai dalam hidupnya. Dengan demikian sekolah sangatlan istimewa sebagai wahana untuk menguatkan pendidikan karakter dalam menanamkan nilai-nilai yang akan merevitalisasikan setiap kehidupan individu menjadi pribadi semakin utuh, dapat menghayati kebebasan, dan menjadi individu yang bertanggung jawab. Momenmomen yang dimiliki sekolah sebagai locus educationis pendidikan karakter di dalam pendidikan akan terurai sebagai berikut:

\section{Sekolah sebagai Wahana Aktialissi Nilai.}

Dalam situasi saat ini untuk mendapatkan pelatihan nilai-nilai moral dalam setiap individu tampaknya tidak mendapat tempat yang layak dalam masyarakat kita, mengingat kultur yang jauh dari nilai moral itu yang telah menyerambah jauh memasuki setiap sendi kehidupan kita. Dalam konteks kehidupan bermasyarakat, hampir tidak dapat ditemukan sesuatu tanpa mentalitas korup dalam berbagai macam bentuk, mulai dari korup uang, waktu, dan penyalahgunaan kewenangan. Lunturnya solidaritas sosial, menggelembungnya semangat kesukuan yang mendasarkan diri pada etnis, agama, gender, dan lain-lainnya, membawa masyarakat semakin berada dalam situasi krisis. Keutuhan bangsa semakin terancam, persatuan semakin terkikis. Hal ini menyebabkan sulitnya mengharapkan bahwa kultur di luar lembaga pendidikan akan dapat membatu mengembangkan pendidikan karakter setiap individu.

Dalam situasi, ketika kultur masyarakat semakin jauh dari penghargaan nilai-nilai kemanusiaan dan moral, sekolah dapat dijadikan wahana yang strategis dalam membentuk, melatih dan mengembangkan semangat kewarganegaraan dalam diri anak didik melalui penanaman nilainilai moral. Komunitas sekolah dapat mengembangkan kesadaran moral individu, dengan menumbuhkan rasa tanggung jawab, baik dikalangan pendidik maupun siswa atas kehidupan mereka saat ini, melalui akuntabilitas kinerja para guru di hadapan 
pemangku kepentingan, seperti; keluarga dan masyarakat. Sekolah tetap menjaga standar mutu akademis yang tinggi berdasarkan nilai-nilai pendidikan karakter yang menjadi priotitas sekolah. Mereka dapat menunjukkan bahwa semangat kebangsaan yang mulai luntur, semangat membela kepentingan rakyat yang terjerat dalam fanatisme sempit dapat diubah lewat pengalaman disekolah melalui penyadaran tenatng pentingnya semangat kebangsaan, melalui konsistensi antara ajaran moral dan perilaku yang tampil dalam diri guru, orang tua dan komunitas. Sekolah dapat menjadi wahana utama untuk menanamkan pengertian bahwa, nilai-nilai moral universal merupakan sebuah ajaran menuju keutamaan yang intergral bagi setiap ranah kurikulum dan jenis kehidupan.

Lembaga pendidiakn memiliki fungsi strategis dalam mengembangkan sebuah penciptaaan lingkungan sekolah yang menghargai kultur yang hormat terhadap nilai-nilai moral. Sekolah bisa menjadikan kesempatan baik bagi guru atau pendidik untuk membuktikan kineja dan integritas professional mereka sehingga mereka mampu memosisikan diri sebagai model bagi keteladan para siswa. Jika dipahami secara lebih konprehensif, sekolah benar-benar menjadi sebuah wahana bagi praksis pendidikan nilai. Di dalam sekolah diharapkan para siswa belajar mengaktualisasikan nilai-nilai yang telah mereka terima secara langsung. Praksis nilai inilah yang menjadi acuan keberhasilan pendidikan karakter di sekolah, sebab karakter hanya bisa dilihat dari prilaku dan praksis, bukan dari pemahaman teoritis.

\section{Perjumpaan adalah Momen Pendidikan Nilai.}

Sekolah akan kehilangan momen istimewa bagi pendidikan nilai, jika setiap individu di dalam lingkungan sekolah tidak menghayati momen perjumpaan dengan individu lain sebagai sebuah kesempatan bagi praksis pendidikan karakter. Setiap perjumpaan sesungguhnya merupakan momen pendidikan nilai itu sendiri. Dalam perjumpaan inilah setiap individu akan merasakan secara langsung apakah dirinya sebagai pribadi yang unik itu diterima di dalm sebuah lingkungan kehidupan social. Dalam perjumpaan inilah seorang individu akan merasakan apakah dirinya diterima dari kebebasannya dihargai. Misalkan perjumpaan guru dengan kepala sekolah, siswa dengan guru, berjumpa dengan sahabat lama dan sebagainya.

Martin Buber menulis bahwa "pada mulanya adalah relasi", manusia menjadi Aku di dalam Engkau. Oleh karena itu, manusia dapat bertumbuh dan berkembang dalam merealisasi diri mereka hanya dalam kebersamaan dengan orang lain. Manusia merupakan sebuah, "ada dalam sebuah relasi", dan oleh sebab itu, struktur dalan antropologisnya adalah terbuka, dalam suatu perjumpaan, dalam sebuah dialog. Dialog mengandaikan adanya pribadi-pribadi yang otonom dan aktif atau magmatik. Hanya dalam relasi seperti inilah teraktualisasikan kebebasan diri yang autentik. Ketika manuisa menyadarkan diri sebagai berada dalam relasi tersebut, disitulah terdapat momen total keberadaan diri manusia.

Perjumpaan dengan yang lain, ini bisa formal terstruktur dan informal. Yang termasuk formal terstruktur tampil dalam momen pendidikan seperti; proses pengajaran dalam kelas, dalam rapat-rapat staf, perjumpaan orang tua siswa dengan wali kelas. Sedangkan perjumpaan informal bisa terjadidi berbagai kesempatan meliputi; perjumpaan antar siswa dengan guru diluar jam pelajaran, baik dikelas, di kantor, di kantin, perjumpaan orang tua siswa dengan anaknya, dan di tempat-tempat di mana pribadi dapat berjumpa dan bertemu.

Perjumpaan di dalam sekolah yang menjadi momen pendidikan nilai sesungguhnya tidak dapat dibatasi sekadar batas-batas pagar sekolah di mana sekolah merasa bertanggung jawab ketika anak berada dalam lingkkungan sekolah. Sementara, kehidupan anak didik 
tidak menjadi tanggung jawab sekolah ketika mereka telah berada di luar pagar sekolah. Pandangan ini terjadi karena pengalaman lapangan menunjukkan bahwa adanya sekolah tertuntu yang memiliki pandangan bahwa, kalau anak masih berada dalam lingkungan sekolah, tanggung jawab keselamatan mereka ada di dalam sekolah. Sedangkan kalau sudah ada di luar pagar sekolah sudah bukan menjadi tanggumng jawab sekolah. Pendapat seperti ini muncul dalam kasus terjadinya tawuran pelajar atau mahasiswa.

Setiap perjumpaan adalah momen pendidikan nilai, karena itu setiap individu di dalam ligkungan sekolah sesungguhnya merupakan partner, rekan kerja, sesama, yang ingin menghayati kebebasannya secara otentik, sehingga keunikan pribadinya menjadi semakin terkukuhkan atau menguat. Kehadiran perjumpaan dengan orang lain menjadi serana peneguh bagi ekpresi keberadaan dirinya, menjadi sebuah saat di mana individu itu bertumbuh dalam kebersamaan.

Pendekatan pendidikan karakter akan integral dan utuh jika pendekatan yang holistik tentang penanaman nilai-nilai itu tidak hanya terjadi dalam relasi antara guru dengan peserta didik di dalam kelas, melainkan juga menuntut sebuah pendekatan yang lebih konprehensif berupa penciptaan linhkup kehidupan moraldi dalam sekolah secara keseluruhan. Sekolah semestinya mencipakan sebuah kultur kehidupan moral dengan cara menggemakan terus menerus ethos sekolah melalui kepemimpinan kepala sekolah, kedisiplinan, rasa bersama sebagai anggota komunitas sekolah.

Jika lingkungan pergaulan di dalam lembaga pendidikan itu sangat kondusif, bersahabat, menjadi sebuah kultur yang menghargai keunikan individu, lembaga pendidikan bukanlah sebuah sekadar tempat pembeajaran, sebuah ruang untuk menuntut ilmu semata, melainkan menjadi tempat untuk memaknai hidup dalam kebersamaan di mana potensi dan talenta individu berkembang dan keunikan individu dihargai. Pendidikan karakter di seklah terarah pada pembentukan lingkungan hidup yang saperti ini.

\section{Wawasan Wiyatamandala pada Orientasi Sekolah sebagai Locus Educationis}

Setiap kali mengawali tahun akademis baru, lembaga pendidikan akan menjumpai wajah-wajah baru yang menjadi anggota komunitas sekolah. Sebagaimana kita menrima kehadirang anggota keluarga baru di dalam keluarga kita, terhadap para anggota baru ini biasanya terdapat acara khusus untuk menerima mereka sebagai dari anggota sebuah komunitas. Upacara penerimaan masuk awal sekolah, lebih umum acara seperti ini disebut (MOS) yaitu Masa Orientasi Sekolah. Kalau pada Perguruan Tinggi Agama seperti di Institut Hindu Dharma Negeri (IHDN) Denpasar mengawali menjadi anggota baru sebuah komunitas kampus, mahasiswa juga melakukan acara untuk pengenalan warga kampus, kemudian dilanjutkan dengan acaranya upacra ritual yang disebut dengan Upanayana. Acara ini terselenggara pada lembaga pendidikan merupakan saat bagi para anggota baru ini mengenal lingkungan sekolah atau lembaga mereka, mulai dari dinamika sekolah, tata peraturan, kebijakan sekolah, anggota sekolah mulai dari Satpam sampai KepaLa Sekolah.

Kegiatan orientasi sekolah saat ini, prinsip dasarnya yang diterapkan adalah bahwa kegiatan ini merupakan saran integritas, pengenalan, dan penggalian kreativitas siswa baru, sehingga sekolah dapat semakin mendampingi dan mengembangkan bakatbakat siswa tersebut. Pada saat masa orientasi sekolah atau kampus inilah terlihat bagaimana individu di dalam lembaga pendidikan tersebut menghayati visi dan misi dari sekolah tempat ia bekerja. Saat-saat seperti ini menjadi saat paling tepat bagi setiap anggota komunitas sekolah tersebut untuk kembali menggali dan mendalami semangat dasar, visi dan misi 
lembaga pendidikan itu, dan menerapkannya bagi perilaku diri sendiri maupun bagi anggota baru yang akan menjadi warga komunitas belajar.

Jika prinsip-prinsip masa orientasi sekolah dapat dijalankan dengan baik, maka masa orientasi ini menjadi momen penting pendidikan karakter siswa di sekolah yang pada gilirannya akan meningkatkan prestasi siswa dan sekolah. Sebuah lingkungan belajar yang mendukung berkembangnya prestasi siswa merupakan sebuah keharusan jika sekolah ingin menanamkan pendidikan karakter bagi sekolah sejak awal.

\section{Manajemen Kelas}

Peristiwa pembelajaran di dalam kelas merupakan momen pendidikan karakter yang sangat strategis. Di dalam kelas guru tak ubahnya seorang manajer yang sedang mengendalikan dan mengarahkan lingkungnya. Dalam perjumpaan antara guru dengan siswa inilah terdapat proses penanaman nilai secara lebih nyata. Guru dengan siswa berhadapan dan berdialog secara langsung sebagai pribadi. Mereka secara bersama-sama membentuk komuntas belajar. Perjumpaan dalam kelas terjadi secara terencana dan teratur melalui penjadwalan mata pelajaran tertentu sesuai dengan kurikulum lembaga pendidikan tersebut. Penjadwalan ini terutama untuk mengorganisir dan mengarahkan agar tujuan pembelajaran tercapai, yaitu penguasaan materi, ketrampilan teknis, penghayatan pribadi tentang objek pembelajaran tertentu.

Berhasil tidaknya pembaharuan dalam pendidikan, entah di tingkat nasional maupun di tingkat local, sangat tergantung pada interprestasi para guru terhadap kebijakan pembaruan tersebut dalam perjumpaan mereka dengan siswa di dalam kelas. Pembaharuan kurikulum kurikulum di tingkat nasional, misalkan, tidak akan efektif jika para guru tidak pernah tidak pernah menerapkan di dalam kelas. Oleh karena itu guru memiliki peran sentral dan strategis bagi setiap pembaharuan pendidikan. Praksis pendidikan karakter di dalam kelas menuntut setiap guru untuk memiliki cara-cara dapat bertindak, pertama sebagai pengasuh, teladan dan pembimbing. Dalam hal ini guru memperlakukan siswanya dengan penuh cinta dan rasa hormat. Kedua, menciptakan sebuah komunitas moral. Para guru semestinya membantu setiap siswa untuk dapat saling mengahargai satu sama lain, memandang yang lain sebagai pribadi yang unik, memiliki rasa hormat, dan saling bertanggung jawab. Ketiga, menegakkan disiplin moral melalui pelaksanaan kesempatan yang telah ditentukan sebagai aturan main bersama.

Tegaknya peraturan moral di dalam kelas menjadi sabuah kesempatan bagi para siswa untuk menguji dan memaknai prilaku bersama melalui penalaran mereka, sehingga mereka dapat menghayati kebebasan mereka selaras dengan ketepatan bersama. Siswa pada akhirnya mengerti bahwa peraturan itu, mesti mengikat mereka. Keempat, guru mengajak siswa agar berani memikirkan dan mengolah persoalan yang berkaitan dengan konfilk moral. Kelima, guru melatih siswa untuk belajar memecahkan konflik yang mncul secara adil dan damai tanpa kekerasan, sehingga para siswa memperoleh ketrampulan moral esensial ketika harus menghadapi persoalan serupa dengan hidup mereka.

\section{Pendidikan Agama sebagai Pembentukan Karakter}

Salah satu perdebatan yang paling hangat yang terjadi dikalangan masyarakat saat ini muncul persoalan agama yang ditungagi politik, sehingga muncul berbagai isu penistaan agama dan pada seputar pendidik di negeri kita adalah persoalan seputar peranan pendidikan agama bagi pembentukan karakter siswa. Negara kita mengakui tentang keesaan Tuhan. Ini menjadi salah satu sila dari Pancasila yang mesti dihayati dan dihidupi oleh setiap warga Negara. Oleh karena itu patutlah kita melihat secara lebih mendalam 
persoalan tentang pendidikan agama ini bagi pembentukan karakter siswa di sekolah. Jika kita memahami pendidikan karakter sebagai sebuah dimensi dari kinerja lembaga pendidikan, setiap momen dalam pendidikan dapat dijadikan wahana pendidikan nilai yang berguna bagi pertumbuhan karakter siswa. Itu sebabnya, bisa pula dikatakan bahwa dalam setiap mata pelajaran terdapat fungsi pedagogis dan edukatif dalam konteks pemebentukan karakter. Dimana keunggulan dan kelemahan pendidikan agama dalam konteks pengembangan pendidikan karakter?

Salah satu pemikir pendidikan karakter kontemporer, Thomas Lickona misalnya, memiliki pandangan bahwa pendidikan karakter dan pendidikan agama semestinya dipisahkan dan tidak dicampur adukkan. Bagi dia, niali-nilai yang berkaitan dengan pendidikan karakter merupakan nilai-nilai dasar yang harus dihayati, jika sebuah masyarakat mau hidup dan bekerja sama secara damai. Nilai-nilai seperti kebijaksanaan, perhormatan terhadap yang lain, tanggung jawab pribadi, perasaan senasib sependeritaan (compassion), pemecah konfilk secara damai, merupakan nilai-nilai yang semestinya di utamakan dalam pendidikan karakter. Bagi dia, (Thomas Lickona) urusan agama bukanlah urusan sekolah negeri ( public school). Pendidikan karakter tidak ada urusan denga ibadat, dan doa-doa yang dilakukan di dalam ,lingkungan sekolah, atau promosi oleh kalangan agama tertentu.

Thomas Lickona dalam (Koesoema, 2010: 250) membedakan secara tegas antara pendidikan karakter dengan pendidiakn agama. Bagi dia agama memilki pola hubungan vertical antara seorang pribadi dengan suatu keyakinan dengan Tuhan. Sedangkan pendidikan karakter adalah pola hubungan horizontal antar manusia dalam masyarakat (individu dangan indivudu lain). Oleh karena itu pendidikan karakter berurusan dengan pengajaran nilai-nilai dasar yang secara virtual dapat diterima oleh masyarakat yang beradab. Dalam konteks kehidupan bermasyarakat di Indonesia, pemisahan teoritis antara pendidikan agama dan pendidikan karakter dalam lembaga pendidikan patutlah dipertanyakan keabsahannya. Sebab pemisahannya itu terjadi, dasar kehidupan bernegara kita akan timpang. Hal ini paling tidak ada dua alasan mengapa argument Lockona kurang tepat.

Pertama, mengatakan bahwa kehidupan religius seseorang merupakan urusan pribadi antara pribadi dan Tuhan, merupakan pemahaman tentang kehidupan bernegara secara keliru, kalu tidak dikatakan distorfit. Sebab sikap hidup keberagamaan dapat menjadi fondasi kokoh bagi pelaksanaan pendidikan karakter terutama agama akan menjadi dasar kokoh tak tergoyahkan bagi pelaksanaan nilai-nilai moral tersebut diyakini sebagai berasal dari perintah Tuhan. Kehidupan rohani yang matang akan membuat manuisa semakin manusiawi.

Kedua, mengatakan bahwa pendidikan karakter merupakan relasi antar individu di dalam masyarakat akan menciptakan corak relasi antar pribadi yang semu. Sebab, individu yang dihormati itu ternyata tidak termasuk keyakinan agamanya. Relasi seperti ini tidak autentik, sebab ia hanya menghormati individu secara parsial. Menghormati individu sesungguhnya juga merupakan kesediaan dan keterbukaan hati untuk menghormati keyakinan iman dan ajaran kepercayaan dari individu tersebut. Oleh karena itu pendidikan karakter jika dipahami secara demikian tidak akan kokoh dan tidak akan stabil, sebab mereka hanya menghargai sebagian dari kekayaan individu. Maka pendidikan karakter sesungguhnya bukan sekadar hubungan horizontal antara individu dan individu lain, tetapi antara individu yang memiliki hubungan vertical dengan Tuhan yang dipercaya dan diimani.

Kehidupamn bersama memang akan stabil jika setiap orang menghayati imannya dengan bebas dan menghormati satu sama lain serta 
bersedia bekerja sama demi kepentingan masyarakat luas. Itulah sebabnya, tujuan pendidikan karakter yang terutama adalah untuk membentuk warga Negara yang bermoral dan terbuka pada kerja sama yang lain. Pendidikan karakter semestinya mengutamakan nilai-nilai yang membantu menciptakan dan menyatukan lingkungan kehidupan social bersama dan stabil.

Undang-Undang Dasar Negara Republik Indonesia Tahun 1945 mengamatkan agar pemerintah mengusahakan dan menyelenggarakan satu system pendidikan nasional yang meningkatkan keimanan dan ketakwaan kepada Tuhan Yang Maha Esa, serta akhlak mulia dalam rangka mencedaskan kehidupan bangsa. Oleh karena itu pendidikan karakter di Indonesia tidak dapat melepaskan diri dari pentingnya pendidikan keimanan dan ketakwaan. Pendidikan karakter di sekolah semestinya meningkatkan iman kepercayaan seseorang membuatnya menjadi manusia pendoa, sekaligus menjadi manusia Indonesia seutuhnya, mampu berbhakti, berjuang, dan bekerja sama demi kepentingan masyarakat bangsa. Manusia seperti inilah yang mampu mencerdaskan kehidupan bangsa.

\section{Pendidikan Jasmani dan Distori bagi Pendidikan karakter.}

Jika pendidikan agama lebih berkaiatan dengan pengembangan pendidikan rohani dalam rangka pendidikan karakter, persoalan juga bisa muncul dalam konteks pendidikan jasmani. Pendidikan karakter dapat tetap bertahan dan mendapatkan dukungan keyakinan kuat ketika ada dasar kerohanian yang menjiwainya. Namun, dasar kerohanian ini tidak akan terwujud tanpa ada kapasitas dan kemampuan fisik manusia dalam merealisasikan cita-citanya. Untuk inilah, program pendidikan jasmani menjadi penting bagi pendidikan karakter.

Pendidikan jasmani dapat memajukan dan mengembangkan berbagai macam ketrampilan yang tidak dapat dipenuhi lewat kurikulum akademis semata. Nilai-nilai yang dapat dikembangkan dalam pendidikan jasmani terutama, nilai-nilai sportivitas, perasaan satu jiwa sebagai warga negara yang diperstukan melalui kegiatan olahraga. Kegiatan olahraga dapat membangkitkan perasaan bangga terhadap sebuah komunitas, mengajarkan kerja sama tim, disiplin diri, dan mempermudah pengembangan emosi dan fisik anak-anak muda bangsa.

Pendidikan jasmani dalam rangka pendidikan karakter terutama tertuju pada proses momen yang kritis dalam pertumbuhan anak-anak, khusunya dalam rangka penciptaan lingkungan masyarakat yang lebih baik. Keterlibatan dalam berolahraga akan memberikan dampak positif bagi anakanak muda terutama dalam mengurangi perilakuyang beresiko secara social, seperti; mabuk minuman keras, berseteru antar siswa. Anak-anak yang tekun melatih diri melalui olahraga dapat mengindarkan dirinya dari perilaku yang tidak sehat., seperti: narkoba, tawuran antarpelajar, atau kebiasaan makan yang buruk. Olehraga terbukti memilki fungsi terapetis dan preventif bagi kesehatan mental dan fisik. Olahraga dapat meningkatkan percaya diri, perasaan positif terhadap fisik yang dimiliki, dan meningkatkan harga diri dalam diri anak didik.

Pendidikan karakter bertujuan membentuk pribadi-pribadi bermoral merupakan landasan yang kokoh dan bermakna bagi setiap pendidikan jasmani. Jika prinsip ini diterapkan, pendidikan kehendak akan menyerambahi segenap demensi kehidupan siswa sehingga mereka dapat bertumbuh secara integral dan utuh.

\section{Pendidikan Estetika bagian Pendidikan Karakter}

Pendidikan seni sejak lama dipakai sebagai salah satu sarana bagi pembentukan karakter seseorang. Dalam mengungkapkan ekspresi berkesenian, peserta didik untuk dapat memiliki apresiasi dan selera seni yang dapat 
membantu perkembangan jiwa individu. Plato, misalkan menganggap penting keseimbangan antara gimnastik dan music agar peserta didik dapat memperkuat bagian rasional dari jiwa, sedangkan gimnastik memperkuat jiwa itu melalui unsur fisiknya. Keseimbangan antara keduanya menghasilkan harmoni yang membantu menyempurnakan keberadaan manusia. Oleh karena itu pendidikan karakter juga memerlukan sebuah penyeimbangan berupa pengalaman kesadaran akan nilai-nilai estetika, nilai-nilai keindahan.

Oleh karena itu pendidikan seni merupakan bagian tak terpisahkan dari pendidikan karakter manuisa. Dengan pendidikan seni, manusia memahami diri sebagai pelaku perubahan, trnasformator, yang mampu mengatasi takdir alam dengan dayadaya kerohaniannya dan inpirasi nilai-nilai dalam dirinya. Dalam pendidikan seni, inpirasi tertinggi kerohanian manusia terwujud secara kasat mata,, entah dalam seni patung, seni music, seni gambar dan lain-liannya. Sebab pada hakekatnya setiap manusia terpanggil untuk menjadi seorang seniman bagi dirinya, yaitu mengatasi kelekatan dan halangan alam yang tidak teratur, dan menundukkannya melalui apresiasi kerohanian yang lebih tinggi yang akan membentuk karakternya sesuai apirasi nilai yang lebih tinggi.

\section{Mengembangkan Kurikulum Secara Integral}

Pendidikan karakter di dalam sekolah dapat semakin efektif dan menjadi tersetruktur jika kurikulum yang dipakai oleh lembag sekolah memilki jiwa pendidikan karakter. Banyak pengamat pendidikan menyatakan bahwa Kurikulum Tingkat Satuan Pendidikan (KTSP) akan mengalami kegagalan justru ketika kebijakan ini diterapkan pada tingkat satuan pendidikan itu sendiri. Kurangnya kopetensi guru dalam merangkai kurikulum, terganggungnya kegiatan belajar mengajar di kelas akibat timing pengenalan KTSP ynag tidak tepat, kekhawatiran kurangnya waktu untuk mempersiapkan siswa menhadapi Ujian Nasional (UN) yang hilang akibat seminarseminar untuk KTSP semakin menambah keyakinan bahwa KTSP benar-benar menjadi sebuah kurikulum tidak siap pakai. Sehingga terbukti, akhirnya munculah kurukulum tiga belas, entah bagaimana pelaksanaanya menjadilah kurikulum KKNI yang sudah diterapkan di beberapa sekolah.

Kurikulum yang dikembangkan di sekolah di masa depan akan menjadi penentu kualitas lembaga pendidikan tersebut. Sebab, ancaman kurikulum inilah akan menentukan apakah pendidikan siswa di sekolah itu memiliki integrasi dan kebutuhan, sehingga mampu menjadi serana bagi siswa untuk mengembangkan kemampuan akademis dan kompetensi social secara utuh.

\section{Kesimpulan}

Penguatan pendidikan karakter di sekolah-sekolah merupakan suatu momen dan wahana sebagai aktualisasi sebuah nilai kehidupan masyarakat masa depan. Sekolah, merupakan wahana untuk menguatkan pendidikan karakter terhadap peserta didik akan menjadi tempat yang efektif bagi pembentukan individu, sehingga mereka dapat tumbuh dan berkembang dengan baik di dalam lingkungannya. Sejak dahulu sekolah memiliki dua tujuan utama dalam karya pendidikan mereka, yaitu membentuk manusia yang cerdas, dan berbudi luhur. Lingkungan sekolah menjadi tempat pendidikan yang baik bagi pertumbuhan peserta didik. Segala peristiwa yang terjadi disekolah semestinya dapat diintegrasikan dalam program pendidikan karakter. Dengan demikian, pendidikan karakter merupakan usaha bersama dari seluruh warga sekolah untuk menciptakan sebuah kultur baru di sekolah, yaitu kultur pendidikan karakter.

Sekolah dengan demikian menjadi tempat istimewa bagi penanaman nilai-nilai dan membantu mengembangkan individu menjadi pribadi yang semakin utuh, menghayati 
kebebasan dan tanggung jawab sebagai individu dan makhluk sosial, untuk itu, patutlah ditelaah momen-momen apa saja dalam sekolah yang dapat dijadikan locos educationis pendidikan karakter di dalam pendidikan. Locus educationis itu antara lain: Sekolah sebagai wahana aktualisasi nilai, setiap perjumpaan guru dengan siswa adalah momen pendidikan nilai, wawasan wiyatamandala sekolah, manajemen sekolah, pendidikan agama bagi pemebentukan karakter, pendidikan jasmani dan distorsi bagi pendidikan karakter, pendidikan estetika dan bahayanya bagi pendidikan karakter, dan pengembangan kurikulum secara integral

\section{DAFTAR PUSTAKA}

Alfian.1980. Politik, Kebudayaan dan Manusia Indonesia. Jakarta: LP3S

Annette. Jhon.2005. "Character, Civic Renewel and Service Learning for Democratic Citizenship in Higner Education".dalam Britis Journal of Educational Studens, Vol.53, No3 (September 2005) 326-340.

Drost, j.1999. Proses pembelajaran sebagai pendidikan. Jakarta: PT. Grasindo.

Fiske, Edward B. 1998. Desentralisasi Pengajaran politik dan Konsensus. Jakarta: PT. Gramedia Widiasarana Indonesia.

Koesoema, A, Doni. 2010. Pendidikan Karakter Strategi Mendidik Anak. Jakarta: Grasindo.

Kaswardi. EM,K.1993. Pendidikan Nilai Memasuki tahun 2000. Katapengantar oleh A. Sewaka SJ. Jakarta: Komisi Pendidikan KWI/MNPK dan PT. Grasindo.
Sjarkawi, M.Pd. 2006. Pembentukan Kepribadian Anak. Peran Moral, Intlektual, Emosional, dan Sosial sebagai Wujud Integritas Membangun Jati Diri, Jakarta: PTBumi Aksara.

Tilaar, H.A.R.2002. Perubahan Sosial dan Pendidikan, Pengantar Pedagogik Transformativ untuk Indonesia, Jakarta: PT. Grasindo.

, 2002. Membenahi Pendidikan Nasional, Jakarta: PT Rineka Cipta. 